\title{
Laboratory Treatments of EAF Slag for Its Use in Construction
}

\author{
Qixing Yang ${ }^{1, a}$, Björn Haase, b, Fenglan $\mathrm{Han}^{3, ~ c}$, Fredrik Engström ${ }^{1, d}$, \\ Jianli $\mathrm{Li}^{4, \mathrm{e}}$, Anjun $\mathrm{Xu}^{4, \mathrm{f}}$ and Bo Björkman ${ }^{1, \mathrm{~g}}$ \\ ${ }^{1}$ Minerals and Metals Research Laboratory, Luleå University of Technology, SE-971 87, Luleå, \\ Sweden \\ ${ }^{2}$ Höganäs Sweden AB, SE-263 83 Höganäs, Sweden \\ ${ }^{3}$ School of Material Science and Engineering, Beifang University of Nationality, Yinchuan, Ningxia \\ 750021, China \\ ${ }^{4}$ Department of Ferrous Metallurgy, School of Metallurgical and Ecological Engineering, University of \\ Science and Technology Beijing, 100083 China \\ a qixing.yang@ltu.se, bijorn.Haase@hoganas.com, '625477897@qq.com, \\ dfredrik.i.engstrom@ltu.se, ${ }^{\mathrm{e}}$ lijianlisteel@163.com, ${ }^{\mathrm{f}}$ anjunxu@126.com, ${ }^{9}$ Bo.Bjorkman@ltu.se
}

Keywords: EAF, Slag, Stabilizer, Laboratory Treatment, Granulation, Leaching, Construction

\begin{abstract}
Laboratory treatments of a plant EAF slag sample 71686 were conducted using stabilizers containing $\mathrm{P}_{2} \mathrm{O}_{5}$ and air granulation. The results show that it is necessary to add the stabilizers to increase contents of $\mathrm{P}_{2} \mathrm{O}_{5}$ from $0.39 \%$ to $0.7 \%$ for the slag stabilization. By a fast air cooling, most of the granules from the granulation are spherical, with a low internal porosity and dense structure. Content of $\mathrm{Fe}_{2} \mathrm{O}_{3}$ in the granules increased from $7.92 \%$ to $18.4 \%$ and $\mathrm{FeO}$ decreased from $14.3 \%$ to $7.8 \%$, due to an oxidation during the slag granulation. Contents of metal elements, As, $\mathrm{Cd}, \mathrm{Cr}, \mathrm{Mo}$, $\mathrm{Pb}, \mathrm{Ni}$ and $\mathrm{Zn}$, in the leachates from the treated slag samples were lower than the limit values for leaching from inert wastes pursuant to Directive 1999/31/EC. The slag samples after the treatments may then be regarded as environmentally friendly to use in construction.
\end{abstract}

\section{Introduction}

At one of the plants of Höganäs Sweden AB in Sweden, steel grades with low carbon contents were produced using an Electric Arc Furnace, EAF. Near the end of EAF heats, liquid steel was tapped to produce metal powder. Liquid slag was also tapped in slag pots for transportation to slag yards, where the slag was poured on the ground for cooling. During cooling on the ground, the EAF slag frequently disintegrated to fine powder [1-2].

Fines from the EAF slag disintegration were often difficult to handle and can lead to air pollution. The slag fines were also not suitable to use as materials for road construction [1-3]. The disintegration is related to the transformation of $\beta-\gamma$ phase of dicalcium silicate, $\mathrm{C}_{2} \mathrm{~S}$, a major mineral phase in some EAF and AOD slags [1-3]. It is thus necessary to carry out slag treatments for stabilization of $\beta-\mathrm{C}_{2} \mathrm{~S}$ in the EAF slag, hence, avoiding formation of the $\gamma-\mathrm{C}_{2} \mathrm{~S}$ and slag disintegration.

The Minerals and Metals Recycling Research Centre, MiMeR, at Luleå University of Technology, LTU, has performed laboratory studies to treat the disintegrated EAF slag in a close cooperation with Höganäs Sweden AB. The studies were conducted as a part of the work for project 88033 in the research program "Towards a Closed Steel Ecocycle" [4]. The program was administrated by Jernkontoret, with financial support from the Foundation for Environment Strategic Research, MISTRA, and industry partners in Sweden. The project 88033, like some other projects, was carried out to enhance utilizations of steel slags as construction materials.

In the first study stage, laboratory treatments to stabilize $\beta-C_{2} S$ in the EAF slag sample from Höganäs Sweden AB were carried out. The EAF slag was melted together with stabilizers containing $\mathrm{P}_{2} \mathrm{O}_{5}$. The re-melted EAF slag was also cooled quickly by air via a granulation system. Slag samples were characterized to evaluate results from the laboratory tests. Researchers from some universities in China also joined some parts of the test and characterization work, financially supported by foundations in China and the CAMM, Center for Advanced Mining and Metallurgy, at LTU. 
Based on results from the laboratory tests, plant-scale tests were carried out in the second study stage. This article describes some of the results from the laboratory treatment studies for the EAF slag, which may be referred to by steel plants in both Sweden and China to treat EAF slags with volume instability, thus enhancing possibilities of using the slags as aggregates or other materials in building applications in the future.

\section{Materials and Equipment for the Laboratory Treatments}

EAF Slag Sample and Stabilizers. Slag samples from several EAF heats were melted in a laboratory induction furnace and a sample from EAF heat with heat number 71686 disintegrated during cooling, which was then selected as the sample for treatment tests and coded as sample 71686. Three stabilizers were used to treat the sample 71686, which was mixed with each of the stabilizers for the laboratory melting tests.

Table 1 Oxide contents in stabilizers, [mass\%]

\begin{tabular}{|c|c|c|c|c|c|c|c|c|}
\hline Stabilizer & $\mathrm{CaO}$ & $\mathrm{SiO}_{2}$ & $\mathrm{MgO}$ & $\mathrm{FeO}$ & $\mathrm{Fe}_{2} \mathrm{O}_{3}$ & $\mathrm{P}_{2} \mathrm{O}_{5}$ & $\mathrm{Al}_{2} \mathrm{O}_{3}$ & $\mathrm{MnO}$ \\
\hline Low-P product & 18.9 & 6.1 & 2.9 & 14.6 & 6.7 & 9.0 & 0.48 & 0.23 \\
\hline MCP-F & 44.8 & 0.9 & 3.6 & & & 47.2 & 0.4 & 0.2 \\
\hline $\mathrm{P}-20$ & 38.8 & 3.7 & 3.1 & & & 45.1 & 0.7 & 0.1 \\
\hline
\end{tabular}

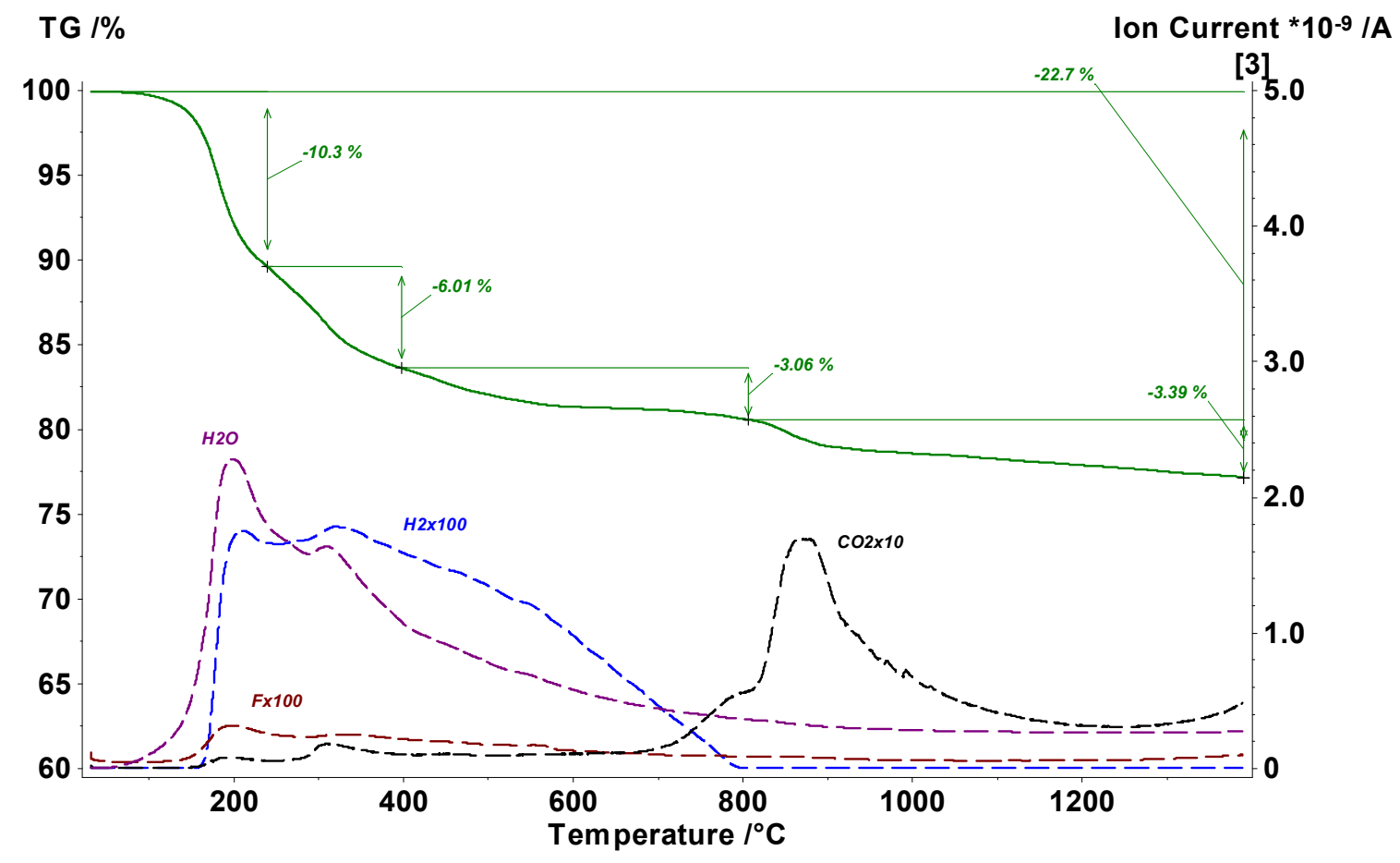

Fig. 1 Curves of TG, thermo-gravimetric analyses, and QMS, quadropole mass spectrometer, for stabilizer MCP-F obtained using a Netzsch STA instrument operated in $20-1400^{\circ} \mathrm{C}$ in $\mathrm{Ar}$ gas

Oxide contents in the three stabilizers are listed in Table 1. The Low-P product, containing 9.0\% $\mathrm{P}_{2} \mathrm{O}_{5}$ and around $20 \%$ Fe oxides, is a by-product of iron ore processing. MCP-F is a feed grade mono-calcium phosphate commercially available, with $\mathrm{P}_{2} \mathrm{O}_{5}$ of $47.2 \%$, a bulk density of around 1.0 $\mathrm{kg} / \mathrm{m}^{3}$ and sizes ranging $0.2-1.5 \mathrm{~mm} . \mathrm{P}-20$ is a fertilizer containing $45.1 \% \mathrm{P}_{2} \mathrm{O}_{5}$ and around $1.7 \% \mathrm{~S}$.

A Netzsch STA instrument for thermo-gravimetric analyses, TG, equipped with a supplemental quadropole mass spectrometer, QMS, was used to heat the stabilizer MCP-F in Ar gas. The TG curve in Fig. 1 indicates a weight loss of $22.7 \%$ at $1400^{\circ} \mathrm{C}$ for $\mathrm{MCP}-\mathrm{F}$, due to $\mathrm{H}_{2} \mathrm{O}$ and $\mathrm{CO} 2$ gas evolving 
near $200^{\circ} \mathrm{C}$ and about $900^{\circ} \mathrm{C}$, respectively, detected by QMS. LOI, loss on ignition, of $26 \%$ was analyzed for $\mathrm{P}-20$, due probably also to $\mathrm{H}_{2} \mathrm{O}$ or $\mathrm{CO}_{2}$ gas formation at high temperature.

\section{Set-ups and Procedures for the Treatment Tests of EAF Slag Sample 71686.}

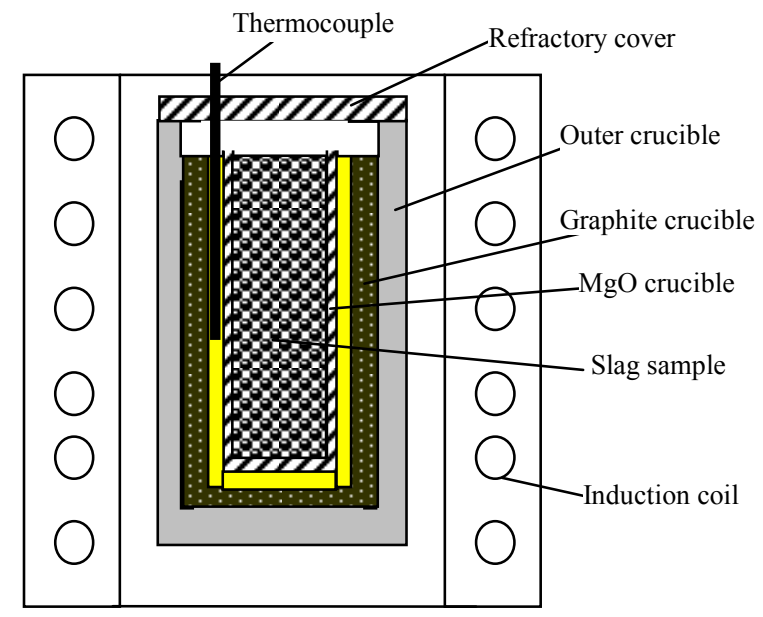

(A)

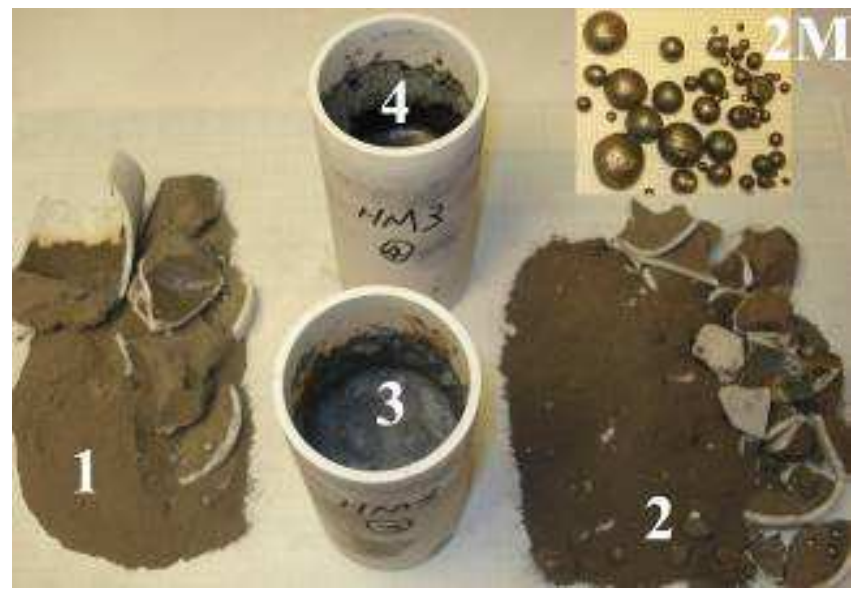

(B)

Fig. 2 (A) Set-up for melting slag sample 71686 and stabilizers and (B) Samples and MgO crucibles after melting tests: 1- HM3-1, 2- HM3-2, 3- HM3-3, 4-HM3-4, 2M- Metal particles separated from slag sample HM3-2

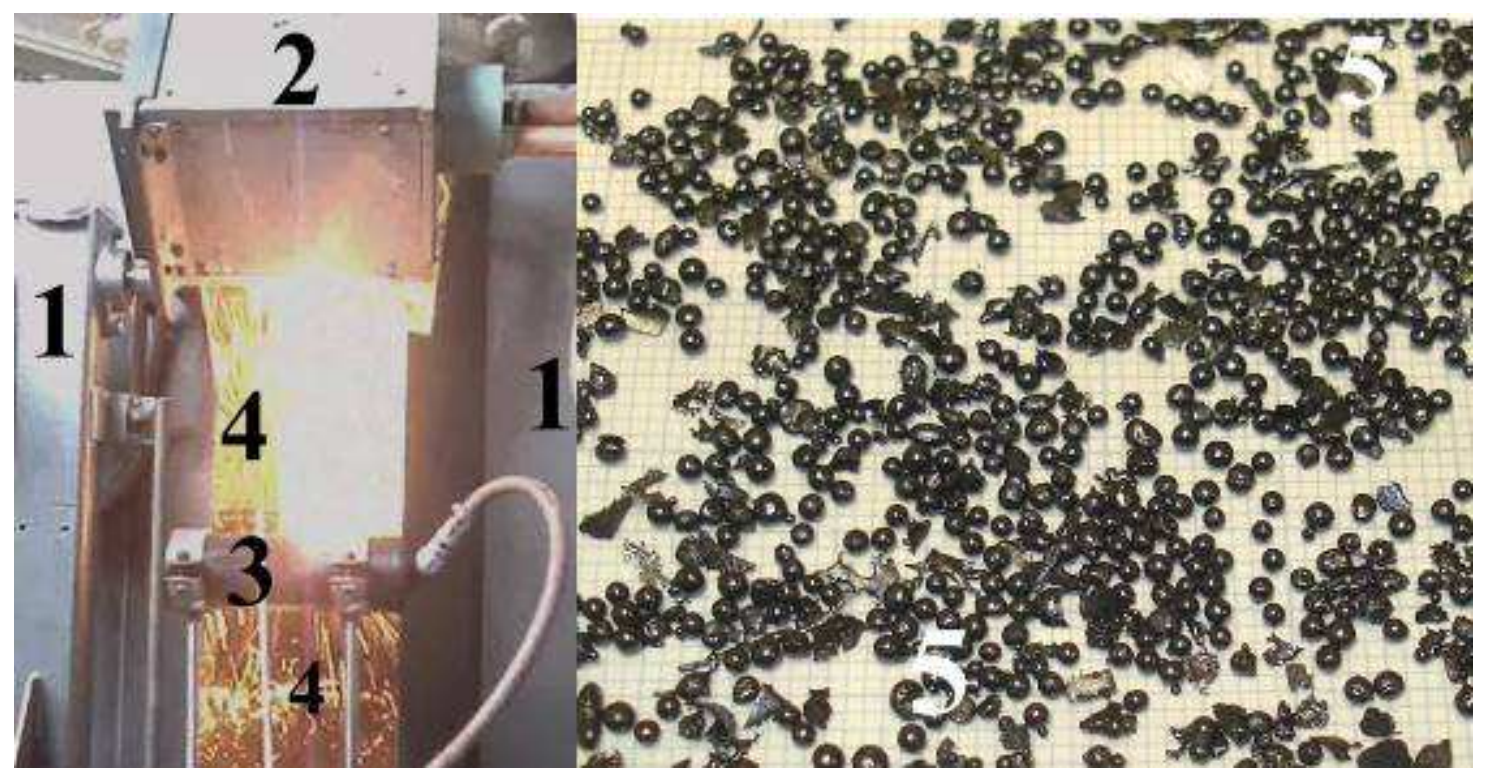

(A)

(B)

Fig. 3 (A) Set-up to granulate the slag sample 71686 by air: 1- Granulation box 2- Induction furnace tilted to pour liquid slag out of $\mathrm{MgO}$ crucible 3- Gas injector 4- Slag granules and (B) 5- Slag granules of $1.18-1.7 \mathrm{~mm}$

A crucible system placed in the induction furnace was used for the treatment tests. Fig. 2A shows the system formed by an inner $\mathrm{MgO}$ crucible, a middle graphite crucible and an outer crucible made of $\mathrm{Al}_{2} \mathrm{O}_{3}$ refractory. The slag sample 71686 and one of the stabilizers were mixed together and contained in $\mathrm{MgO}$ crucibles. A thermocouple between the $\mathrm{MgO}$ and graphite crucibles measured temperature in the system for controlling the induction power to heat the slag/stabilizer to around $1610^{\circ} \mathrm{C}$ with a heating rate of $4.2^{\circ} \mathrm{C} /$ minute. The level of $1610^{\circ} \mathrm{C}$ was then maintained for 20 minutes, followed by switching off the furnace power with the melted samples left inside the system to cool to room temperature in 5 hours. 
After the cooling, the $\mathrm{MgO}$ crucibles were removed from the system for inspection. A treatment of the slag sample by the stabilizers was considered to be successful with neither fine generation nor breakage of the crucible caused by slag volume expansion. A picture of stabilized slag samples inside the crucibles and slag fines together with pieces of broken crucibles is seen in Fig. 2B. Other details regarding the crucible system and furnace operation can also be found in [1-3].

Air granulation tests were carried out to examine effects of fast air cooling on slag stabilization. The sample 71686 of about $1.0 \mathrm{~kg}$ was melted in $\mathrm{MgO}$ crucible. A granulation box (1 in Fig. 3A) made of steel plates was placed with an open side in front of the induction furnace to receive slag particles from the granulation. While the slag temperature was around $1600^{\circ} \mathrm{C}$, an injector $(3$ in Fig. $3 \mathrm{~A}$ ) under the furnace started to inject air into the granulation box and the furnace (2 in Fig. 3A) was tilted to pour the liquid slag out of the crucible. The slag stream was impinged by air jet to generate slag granules (4 in Fig. 3A). The slag granules of 1.18-1.7 mm from one of the granulation tests are shown by part 5 in the picture of Fig. 3B. The slag granulation lasted for around 1 minute, with air flow rate and pressure of $66 \mathrm{Nm}^{3} / \mathrm{h}$ and 5 bars, respectively.

\section{Results from the Laboratory Treatments and Discussions}

Results from Treatments of Samples $\mathbf{7 1 9 8 9}$ by Using the Stabilizers. The slag samples 71686, weighing 50-400 g, were mixed together with each of the stabilizers containing $\mathrm{P}_{2} \mathrm{O}_{5}$ for melting tests, with values of mass percentage for the stabilizers in the samples listed in Table 2.

Table 2 Amounts of stabilizers [mass\%] mixed in slag sample 71686 for melting tests (A sum of mass percentages for a stabilizer and slag equals to $100 \%$ )

\begin{tabular}{|c|c|c|c|c|c|c|c|c|c|c|c|}
\hline Stabilizer & \multicolumn{3}{|c|}{ Low-P product } & \multicolumn{4}{c|}{ P20 } & \multicolumn{4}{c|}{ MCP-F } \\
\hline$[$ mass\% & 1 & 1.96 & 2.91 & 0.3 & 0.6 & 0.9 & 1.2 & 0.2 & 0.4 & 0.6 & 0.8 \\
\hline
\end{tabular}

$P$ contents in Metal Particles. Picture part 2M in Fig. 2B shows the metal particles separated from slag sample HM3-2. It is also seen in picture on right hand side of Fig. 4 that some metal particles exist in slag sample HM5-1 near to the crucible bottom. Metal particles obtained from slag samples after some treatment tests were analysed for P contents.

Table $3 \mathrm{P}$ contents in metal particles retrieved from slag after melting sample 71686 together with stabilizers containing $\mathrm{P}_{2} \mathrm{O}_{5}$, (sum of mass percentages for a stabilizer and slag equaling to $100 \%$ )

\begin{tabular}{|c|c|c|c|c|c|c|c|c|}
\hline \multirow{2}{*}{ Stabilizer } & Type & \multicolumn{3}{|c|}{ Low-P product } & P20 & \multicolumn{2}{c|}{ MCP-F } \\
\cline { 2 - 9 } & Mixed in slag, [mass\%] & 0 & 1.0 & 1.96 & 2.91 & 1.2 & 0.6 & 0.8 \\
\hline $\begin{array}{c}\text { P content in metal particles from } \\
\text { slag, [mass \%] }\end{array}$ & 0.008 & 0.008 & 0.012 & 0.012 & 0.005 & 0.005 & 0.005 \\
\hline
\end{tabular}

Using Low-P product of $1.96 \%$ and $2.91 \%$ in the slag samples, $\mathrm{P}$ contents in metal particles increased slightly by $0.004 \%$ to $0.012 \%$, as seen in Table 3 . The metal P contents were $0.005 \%$ and did not increase while using the high $\mathrm{P}_{2} \mathrm{O}_{5}$ stabilizers $\mathrm{P} 20$ and MCP-F. The results indicate that there was hardly any $\mathrm{P}$ dissolved in metal particles from the stabilizers and $\mathrm{P}_{2} \mathrm{O}_{5}$ in the stabilizers, thus, remained largely in the slag for crystal chemical stabilization of volume stable $\mathrm{C}_{2} \mathrm{~S}$ polymorphs.

Stabilizer-Low-P Product. Picture parts 1 and 2 in Fig. 2B show re-melted slag sample 71686 coded as HM3-1 and the sample 71686 melted together with 1\% Low-P product coded as HM3-2, respectively, being disintegrated with the slag volume expansion that cracked $\mathrm{MgO}$ crucibles to pieces. Some slag parts in the sample melted with $1.96 \%$ Low-P product, HM3-3, were seen with a weaker structure, but there were no fines in the sample and the $\mathrm{MgO}$ crucible was not broken, as indicated by part 3 in Fig. 2B. The sample 71686 melting together with $2.91 \%$ Low-P product, HM3-4, was stabilized and solidified in $\mathrm{MgO}$ crucible as shown by part 4 in Fig. 2B. 
Stabilizer-P20 and MCP-F. Picture on left hand side of Fig. 4 shows a crack formed on wall of $\mathrm{MgO}$ crucible containing sample 71686 melted together with $0.3 \%$ P20, HM4-1. No crack and fines were observed by increasing P20 to $0.6-1.2 \%$ and the samples were stable and solidified in $\mathrm{MgO}$ crucibles.

Picture on right hand side of Fig. 4 shows a small amount of fines formed in slag sample HM5-1, the sample 71686 melted together with $0.2 \%$ MCP-F. By increasing MCP-F mixed in the samples from 0.2 to $0.6 \%, \mathrm{P}_{2} \mathrm{O}_{5}$ contents increased from 0.43 to $0.67 \%$ and no fines were generated in the stabilized sample, Table 4.

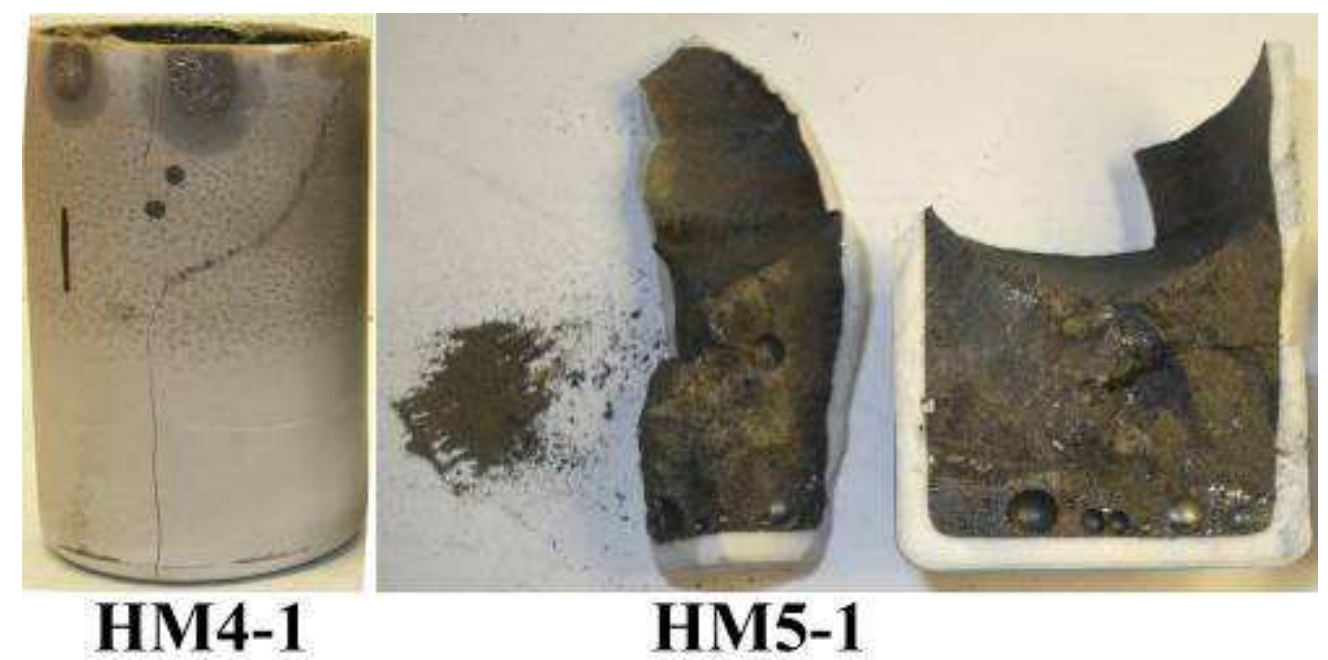

Fig. $4 \mathrm{MgO}$ crucible containing slag sample 71686 melted with $0.3 \%$ P20, HM4-1, on the left hand side and a small amount of fines and solidified slag obtained after melting of sample 71686 with $0.2 \%$ MCP-F, HM5-1, on the right hand side

Table 4 Oxide contents in the samples from melting slag sample 71686 mixed together with stabilizer P20 and MCP-F

\begin{tabular}{|c|c|c|c|c|c|c|c|c|c|}
\hline \multicolumn{2}{|l|}{ Stabilizer } & \multicolumn{7}{|c|}{ Oxide content [mass $\%]$} & \multirow{2}{*}{$\begin{array}{c}\text { Slag } \\
\text { stable }\end{array}$} \\
\hline Type & $\%$ & $\mathrm{CaO}$ & $\mathrm{SiO}_{2}$ & $\mathrm{FeO}$ & $\mathrm{MgO}$ & $\mathrm{Al}_{2} \mathrm{O}_{3}$ & $\mathrm{P}_{2} \mathrm{O}_{5}$ & $\mathrm{MnO}$ & \\
\hline $\mathrm{P} 20$ & 1.2 & 41.1 & 16.1 & 15.8 & 5.3 & 7.3 & 0.94 & 4.9 & Yes \\
\hline \multirow{2}{*}{ MCP-F } & 0.2 & 41.0 & 15.6 & 13.6 & 4.6 & 8.9 & 0.43 & 5.0 & No \\
\hline & 0.6 & 42.4 & 16.1 & 16.5 & 4.9 & 8.8 & 0.67 & 5.2 & Yes \\
\hline
\end{tabular}

Characterizations of Samples Treated by the Stabilizer Low-P Product. $\mathrm{P}_{2} \mathrm{O}_{5}$ content in the original EAF slag sample 71686 is $0.39 \%$. The fines from re-melting of the sample 71686 , coded as HM06fi in Table 5 contain $0.46 \% \mathrm{P}_{2} \mathrm{O}_{5}$. With the low contents of $0.39-0.46 \%$, the $\mathrm{P}_{2} \mathrm{O}_{5}$ can only stabilize a small part of $\beta-\mathrm{C}_{2} \mathrm{~S}$. Thus $\gamma-\mathrm{C}_{2} \mathrm{~S}$, phase 3 , exists as a major phase in the sample HM06fi, indicated by the upper XRD graph in Fig. 5, which generated slag fines similar to those shown by picture part 1 in Fig. 2B.

By adding $2.91 \%$ Low-P product to increase $\mathrm{P}_{2} \mathrm{O}_{5}$ content to $0.71 \%$ in sample HM3-4, $\beta-\mathrm{C}_{2} \mathrm{~S}$, phase 4 , became a dominant phase and $\gamma-\mathrm{C}_{2} \mathrm{~S}$ disappeared, indicated by the lower XRD graph in Fig. 5, which led to a volume stable slag solidifying in $\mathrm{MgO}$ crucible as shown by picture part 4 in Fig. $2 \mathrm{~B}$.

It can be summarized by combining results in the Tables 4 and 5, as well as the pictures shown in Fig. 2B and Fig. 4, that it is necessary to add, at least, either $2.91 \%$ Low-P product or $0.6 \%$ P20 or $0.6 \% \mathrm{MCP}-\mathrm{F}$ in order to stabilize the EAF slag sample 71686 . The stabilizer additions can increase contents of $\mathrm{P}_{2} \mathrm{O}_{5}$ in the slag from $0.39 \%$ to around $0.7 \%$. 
Table 5 Analyses [mass\%] of original slag sample 71686 and the slag sample melted with and without using the stabilizer Low-P product

\begin{tabular}{|c|c|c|c|}
\hline Sample code & Original 71686 & HM3-4 & HM06fi \\
\hline $\mathrm{CaO}$ & 41.3 & 43.5 & 43.5 \\
\hline $\mathrm{MgO}$ & 6.19 & 6.43 & 7.96 \\
\hline $\mathrm{SiO}_{2}$ & 14.5 & 15.6 & 16.2 \\
\hline $\mathrm{Al}_{2} \mathrm{O}_{3}$ & 7.25 & 7.76 & 6.61 \\
\hline $\mathrm{MnO}$ & 6.11 & 5.1 & 5.37 \\
\hline $\mathbf{P}_{2} \mathbf{O}_{\mathbf{5}}$ & $\mathbf{0 . 3 9}$ & $\mathbf{0 . 7 1}$ & $\mathbf{0 . 4 6}$ \\
\hline $\mathrm{Cr}_{2} \mathrm{O}_{3}$ & 0.25 & 0.25 & 0.25 \\
\hline $\mathrm{TiO}_{2}$ & 0.59 & 0.67 & 0.63 \\
\hline $\mathrm{CaO}_{\mathrm{SiO}}$ & 2.85 & 2.79 & 2.69 \\
\hline \multicolumn{2}{|r|}{$\mathrm{Treatments:}_{2}$ Re-melting } & Yes & Yes \\
\% of Low-P product added & 2.91 & 0 \\
Sample character & Lumps & Fins \\
\hline
\end{tabular}

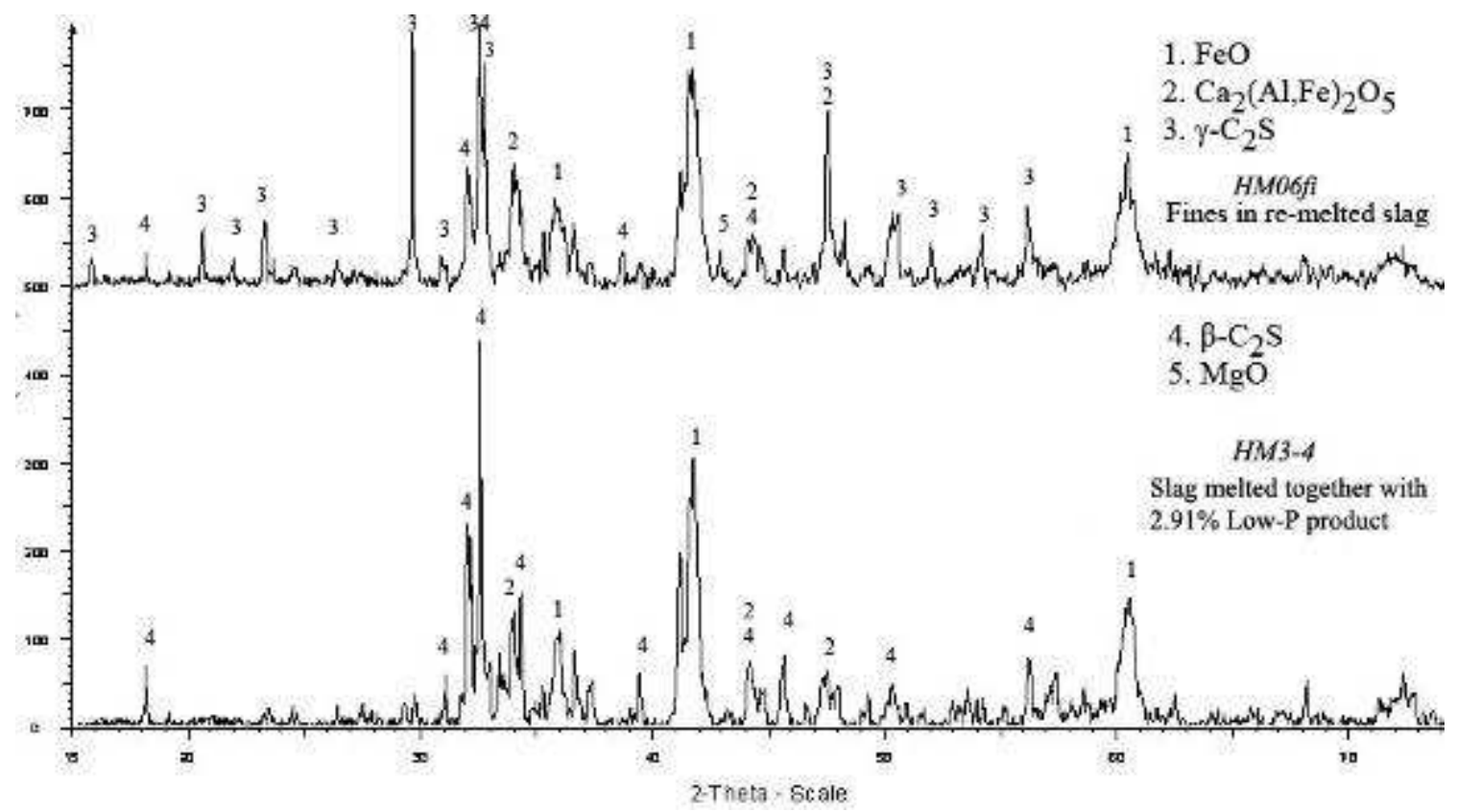

Fig. 5 XRD analyses of slag samples, upper XRD pattern for the slag fines from re-melting of sample 71686, HM06fi, and lower XRD pattern for sample 71686 melted together with 2.91\% Low-P product, HM3-4

Characterizations of Samples Treated by Air Granulation. The $\gamma-\mathrm{C}_{2} \mathrm{~S}$ disappeared in the slag samples from the air granulation as indicated by XRD patterns in Fig. 6 . Near $80 \%$ of the granules were greater than $0.425 \mathrm{~mm}$, determined by a sieving analysis. These granules were mostly spherical as shown by part 5 in the picture of Fig. 3B. SEM picture in Fig. 7 indicates that smaller granules with sizes around $160 \mu \mathrm{m}$ are also spherical with a low internal porosity and a dense structure, resulted from the fast air cooling.

The granules of $<425 \mu \mathrm{m}$ obtained from test HG6 could be cooled with a higher rate than the granules with sizes of 1.7-2.36 mm. The $\mathrm{C}_{2} \mathrm{~S}$ phase existing at high temperature, $\alpha^{\prime}-\mathrm{C}_{2} \mathrm{~S}$, was then preserve largely in the granules of $<425 \mu \mathrm{m}$ by the higher cooling rate and detected as a major $\mathrm{C}_{2} \mathrm{~S}$ phase, phase 3 in the upper XRD graphs in Fig. 6.

For the larger granules with sizes of 1.7-2.36 mm, the cooling rate may be lower than the rate for the smaller granules. Some parts of the high temperature phase $\left(\alpha^{\prime}-C_{2} S\right)$ can then be transferred to the phase existing at lower temperature $\left(\beta-C_{2} S\right)$, while the granules were cooled slower. The slower 
cooling may lead to a co-existence of both high and low temperature phases, $\alpha^{\prime}-\mathrm{C}_{2} \mathrm{~S}$ and $\beta-\mathrm{C}_{2} \mathrm{~S}$, in the granules of 1.7-2.36 mm detected as phase 2 and 3 in the lower XRD graph of Fig. 6.

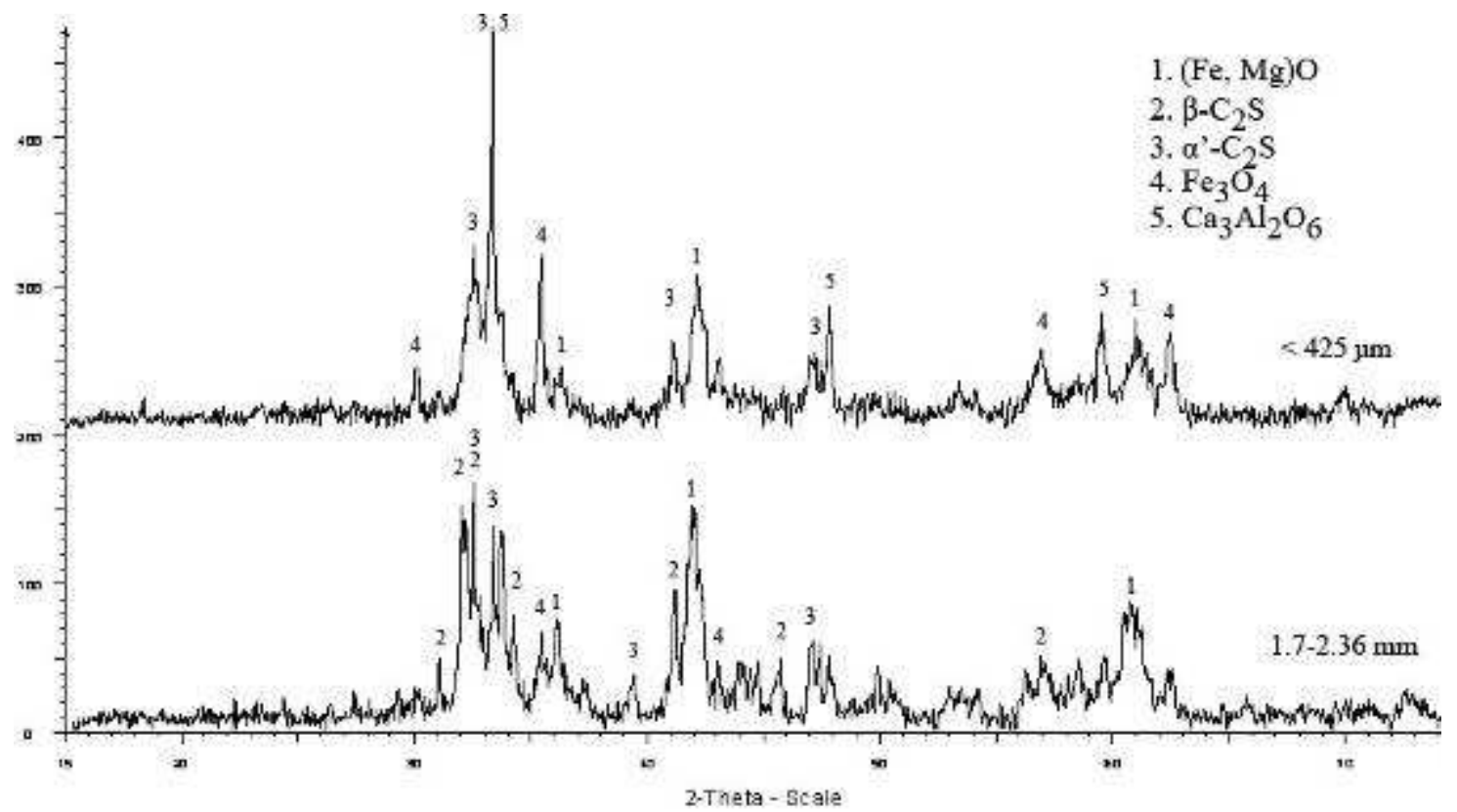

Fig. 6 XRD analyses of slag granules from test HG6, air granulation of slag sample 71686

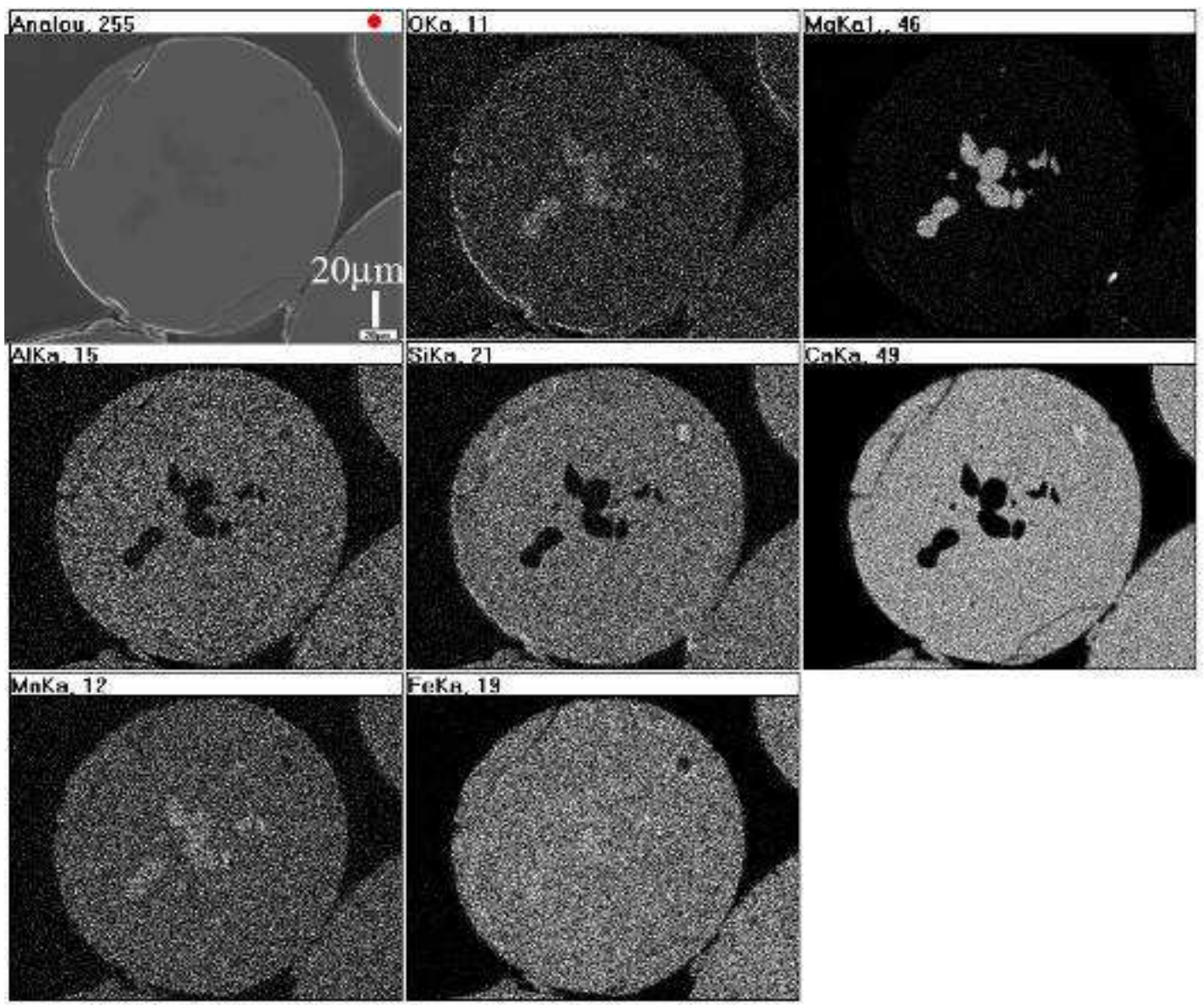

Fig. 7 SEM element mapping of a granule from test HG6 with size around $160 \mu \mathrm{m}$

$\mathrm{Ca}_{3} \mathrm{Al}_{2} \mathrm{O}_{6}$, phase 5 in the upper XRD graphs in Fig. 6 , is one of the primary minerals in ordinary Portland cement with a high hydraulic activity [5]. This phase together with $\alpha^{\prime}-C_{2} S$ and $\beta-C_{2} S$ or phases 2, 3 and 5 in the XRD graphs of the figure may make the $<425 \mu \mathrm{m}$ granules suitable to use as hydraulic binder or as a material mixed in the cement. 
By the air oxidation, content of $\mathrm{Fe}_{2} \mathrm{O}_{3}$ in the granules increased from $7.92 \%$ to $18.4 \%$ and $\mathrm{FeO}$ decreased from $14.3 \%$ to $7.8 \%$, Table $6 . \mathrm{Fe}_{3} \mathrm{O}_{4}$ was also detected in the granules as phase 4 in Fig. 6, resulting from the oxidation. $\mathrm{Fe}_{2} \mathrm{O}_{3}$ can stabilize $\beta-\mathrm{C}_{2} \mathrm{~S}$ phase [5]. Both $\mathrm{Fe}_{2} \mathrm{O}_{3}$ and $\mathrm{Fe}_{3} \mathrm{O}_{4}$ can react with $\mathrm{CaO}$, decreasing amount of $\mathrm{CaO}$ available for $\mathrm{C}_{2} \mathrm{~S}$ formation, as well as content of free $\mathrm{CaO}$ in the slag $[6,7]$.

Table 6 Analyses [mass\%] of slag sample 71686 and HG6, the sample treated by air granulation

\begin{tabular}{|c|c|c|}
\hline Sample code & Original 71686 & Granules HG6 \\
\hline $\mathrm{CaO}$ & 41.3 & 39.2 \\
\hline $\mathrm{MgO}$ & 6.19 & 6.63 \\
\hline $\mathrm{SiO}_{2}$ & 14.5 & 14.3 \\
\hline $\mathrm{Al}_{2} \mathrm{O}_{3}$ & 7.25 & 6.5 \\
\hline $\mathrm{MnO}$ & 6.11 & 4.91 \\
\hline $\mathbf{P}_{\mathbf{2}} \mathbf{O}_{\mathbf{5}}$ & $\mathbf{0 . 3 9}$ & $\mathbf{0 . 4 1}$ \\
\hline $\mathrm{Cr}_{2} \mathrm{O}_{3}$ & 0.25 & 0.25 \\
\hline $\mathrm{TiO}_{2}$ & 0.59 & 0.52 \\
\hline $\mathrm{Fe}_{2} \mathrm{O}_{3}$ & 7.92 & 18.4 \\
\hline $\mathrm{FeO}$ & 14.3 & 7.8 \\
\hline $\mathrm{Fe}-\mathrm{met}$ & 1.67 & 1.39 \\
\hline
\end{tabular}

Element mapping of a granule of size $160 \mu \mathrm{m}$, Fig. 7, reveals that micro-particles near center of the granule and with sizes around $20 \mu \mathrm{m}$ consisted mainly of $\mathrm{Mg}, \mathrm{Mn}, \mathrm{Fe}$ and $\mathrm{O}$ elements. The particles may be $\mathrm{MgO}$ particles or particles generated by free $\mathrm{MgO}$ forming solid solutions with divalent oxides, such as $\mathrm{MnO}$ and $\mathrm{FeO}$. It is possible that XRD analyzed the particles as $(\mathrm{Fe}, \mathrm{Mg}) \mathrm{O}$ phase in the granules (phase 1 in XRD graphs of Fig. 6). The mapping also shows that other compounds containing $\mathrm{Ca}, \mathrm{Si}, \mathrm{Fe}, \mathrm{Al}$ and $\mathrm{O}$ elements encircle these free $\mathrm{MgO}$ and $(\mathrm{Fe}, \mathrm{Mg}) \mathrm{O}$ particles.

The micro-particles of $\mathrm{MgO}$ and particles formed by $\mathrm{MgO}, \mathrm{MnO}$ and $\mathrm{FeO}$ observed in Fig. 7 may be solidified first during the high-speed air cooling. An oxidation of $\mathrm{FeO}$ by air decreased $\mathrm{FeO}$ content and, thus, increased $\mathrm{Fe}_{2} \mathrm{O}_{3}$ and $\mathrm{Fe}_{3} \mathrm{O}_{4}$ contents, Table 6, making it possible to form compounds rich in $\mathrm{Ca}, \mathrm{Si}, \mathrm{Fe}$ and $\mathrm{Al}$. These compounds or phases possess a lower melting temperature and thus solidify later to encase the micro-particles of $\mathrm{MgO}$ and particles of $\mathrm{MgO}$ solid solutions formed early.

The rate of hydration for free $\mathrm{MgO}$ is usually lower than free $\mathrm{CaO}$ [7]. A long weathering period is then required to avoid impact of $\mathrm{MgO}$ hydration on volume stability of the slag containing more than $5 \%$ of $\mathrm{MgO}$. $\mathrm{MgO}$ contents in the EAF slag samples for the present tests were higher than $6 \%$, Tables 5 and 6 . The air granulation led to an oxidization of $\mathrm{FeO}$ on the slag surface and a formation of dense slag layer by, mainly, $\mathrm{Ca}, \mathrm{Si}, \mathrm{Fe}$ and $\mathrm{Al}$ elements. The dense slag layers enclosing micro-particles of $\mathrm{MgO}$ and $\mathrm{MgO}$ solid solutions near centers of granules, seen in Fig. 7, may then eliminate water accessibility and, hence, the possibility to hydrate for the free $\mathrm{MgO}$ particles.

The air granulation, through quick cooling and oxidation of $\mathrm{FeO}$, not only retained the high temperature, stable $\mathrm{C}_{2} \mathrm{~S}$ phases, but also minimized tendency of expansive hydration for free lime and magnesia in the granules. The formation of a dense surface layer by $\mathrm{Ca}, \mathrm{Si}, \mathrm{Fe}$ and $\mathrm{Al}$ elements would make the slag granules not only stable against chemical and physical weathering, but also useable in many building and other applications with better properties than natural materials [6].

Environment Properties of the Stabilized Slag. Results from the leaching test using EN 12457-2 [8] and slag samples from the treatment tests are presented in Table 7. The EN 12457-2 is one of the test methods to characterize materials for the acceptance of wastes in landfills pursuant to Directive 1999/31/EC II [9]. Limit values of element leaching from inert waste acceptable at landfills were set in the Directive. A material is generally considered as environmentally friendly to use as construction material if the leaching values of elements from the material are lower than the limit values set for the inert waste. Limit values for leaching of some important elements are also listed in Table 7. 
Table 7 Content of metal elements, $\mathrm{pH}$ and conductivity for leachates from tests EN 12457-2 of slag sample 71686, the sample granulated (HG6), re-melted (HM06fi) and stabilized by 2.91\% Low P-product (HM3-4), as well as limit values for inert waste [9]

\begin{tabular}{|c|c|c|c|c|c|}
\hline $\begin{array}{c}\text { Sample } \\
\text { Element }[\mathrm{mg} / \mathrm{kg}]\end{array}$ & $\begin{array}{c}\text { Granule } \\
\text { HG6 }\end{array}$ & HM3-4 & HM06fi & $\begin{array}{c}\text { Original } \\
71686\end{array}$ & $\begin{array}{c}\text { Limit value for } \\
\text { inert waste [9] }\end{array}$ \\
\hline $\mathrm{Ca}$ & 318.6 & 2681.4 & 1884.4 & 2859.1 & \\
\hline $\mathrm{K}$ & 5.01 & 21.61 & 50.82 & 15.50 & \\
\hline $\mathrm{Mg}$ & 3.57 & 0.90 & 0.90 & 0.90 & \\
\hline $\mathrm{Na}$ & 9.89 & 21.21 & 54.13 & 16.69 & \\
\hline $\mathrm{S}$ & 3.20 & 2.00 & 2.00 & 2.00 & \\
\hline $\mathrm{Al}$ & 43.69 & 948.49 & 606.41 & 1329.59 & \\
\hline $\mathrm{As}$ & 0.165 & 0.010 & 0.010 & 0.020 & 0.5 \\
\hline $\mathrm{Ba}$ & 0.569 & 4.542 & 20.949 & 7.518 & 20 \\
\hline $\mathrm{Cd}$ & 0.001 & 0.001 & 0.001 & 0.001 & 0.04 \\
\hline $\mathrm{Cr}$ & 0.393 & 0.001 & 0.001 & 0.010 & 0.5 \\
\hline $\mathrm{Mo}$ & 0.157 & 0.013 & 0.012 & 0.067 & 0.5 \\
\hline $\mathrm{Ni}$ & 0.001 & 0.006 & 0.001 & 0.010 & 0.4 \\
\hline $\mathrm{P}$ & 0.233 & 0.430 & 0.100 & 0.200 & \\
\hline $\mathrm{Pb}$ & 0.002 & 0.002 & 0.002 & 0.004 & 0.5 \\
\hline $\mathrm{Zn}$ & 0.020 & 0.077 & 0.129 & 0.040 & 4.0 \\
\hline $\mathrm{pH}$ & 11.55 & 12.51 & 12.46 & 12.39 & \\
\hline Conductivity $\mu \mathrm{S} / \mathrm{cm}$ & 262 & 2050 & 1820 & 1970 & \\
\hline
\end{tabular}

The amounts of $\mathrm{Ca}, \mathrm{Al}$ and $\mathrm{Ba}$ leached and $\mathrm{pH}$ and conductivity values of the leaching liquid for the granulated sample HG6 were lower than those for the slow cooled slag samples, Table 7. As, Mo and $\mathrm{Cr}$ elements leached from the granules were increased slightly as compared with the slag samples. Oxidation of metal elements in oxides of As, $\mathrm{Mo}$ and $\mathrm{Cr}$ by air during the granulation may lead to the leaching increases. Other gases with less oxygen contents than air may be used for the granulation to prevent the leaching increases for the elements.

It is also seen in Table 7 that contents of metal elements, such as $\mathrm{As}, \mathrm{Cd}, \mathrm{Cr}, \mathrm{Mo}, \mathrm{Pb}, \mathrm{Ni}$ and $\mathrm{Zn}$ in the leaching liquid from the treated samples, HG6 and HM3-4, were lower than the limit values for leaching of inert wastes pursuant to Directive 1999/31/EC [9]. The treated samples may then be usable in construction as environmentally friendly materials.

\section{Summary}

The present laboratory tests treated disintegrated EAF slag sample 71686 from the plant with using stabilizers containing $\mathrm{P}_{2} \mathrm{O}_{5}$ and by air granulation. The following results are achieved:

1. It is necessary to add, at least, either $2.91 \%$ Low-P product (containing $9 \% \mathrm{P}_{2} \mathrm{O}_{5}$ ) or $0.6 \% \mathrm{P} 20$ (containing $45.1 \% \mathrm{P}_{2} \mathrm{O}_{5}$ ) or $0.6 \% \mathrm{MCP}-\mathrm{F}$ (containing $47.2 \% \mathrm{P}_{2} \mathrm{O}_{5}$ ) for a stabilization of the sample 71686. Contents of $\mathrm{P}_{2} \mathrm{O}_{5}$ in the slag can be increased to $0.7 \%$ from $0.39 \%$ by the stabilizer additions.

2. Most of the granules from the air granulation are spherical, with a low internal porosity and dense structure, resulting from the fast air cooling. By the air oxidation, content of $\mathrm{Fe}_{2} \mathrm{O}_{3}$ in the granules increased from $7.92 \%$ to $18.4 \%$ and $\mathrm{FeO}$ decreased from $14.3 \%$ to $7.8 \%$.

3. The $\gamma-C_{2} S$ disappeared in the samples from the granulation. Both $\alpha^{\prime}-C_{2} S$ and $\beta-C_{2} S$ were presented in larger granules of 1.7-2.36 mm. The $\alpha^{\prime}-\mathrm{C}_{2} \mathrm{~S}$, existing at high temperature, was preserve largely in the granules of $<425 \mu \mathrm{m}$. A mineral phase with high hydraulic activity, $\mathrm{Ca}_{3} \mathrm{Al}_{2} \mathrm{O}_{6}$, was also detected in the granules of $<425 \mu \mathrm{m}$, making them suitable to use as hydraulic binder or in cement.

4. Contents of metal elements, such as $\mathrm{As}, \mathrm{Cd}, \mathrm{Cr}, \mathrm{Mo}, \mathrm{Pb}, \mathrm{Ni}$ and $\mathrm{Zn}$, in the leachates from the treated samples were lower than the limit values for leaching of landfilled inert waste pursuant to Directive 1999/31/EC. The treated slag samples may then be considered as environmentally friendly to use as construction materials. 


\section{Acknowledgements}

The authors thank Foundation for Strategic Environmental Research, Mistra, (the steel Eco-Cycle), Höganäs Sweden AB and CAMM, Center for Advanced Mining and Metallurgy at Luleå University of Technology, LTU, for financial support. Mr. Jianli Li has been supported financially by Chinese Scholarship Council and CAMM for PhD training at LTU. Besides, researches from Beifang University of Nationality and, LTU, have been supported by CAMM for visiting and performing joint research work.

\section{References}

[1] Qixing Yang, et al.: In: REWAS 2008: Global Symposium on Recycling, Waste Treatment. Minerals, Metals \& Materials Society, (2008), p. 49

[2] Qixing Yang, et al.: In: Proceedings of Asia Steel 2012, Sept. 23-27, 2012, Beijing, China

[3] Qixing Yang et al., In: Proceedings of The Iron \& Steel Technology Conference, AISTech 2006, May 1-4, Cleveland, Ohio, USA (2006),Volume 1, p. 573

[4] Information on http://www.jernkontoret.se/english/research/the_steel_eco_cycle/index.php

[5] Surendra N. et al., Journal of Materials Science, 14 (1979), p. 1554

[6] "Blast Granulation System of BOF Slag and Its Products", NIPPON KOKAN TECHNICAL REPORT, Overseas, No. 38, 1983

[7] L. M. Juckes, Mineral Processing and Extractive Metallurgy (Trans. Inst. Min. Metall. C), December 2003 Vol. 112. C177

[8] Final draft prEN 12457-2, Characterization of waste-Leaching-Compliance test of leaching of granular waste material and sludges -Part 2: One stage batch test at a liquid to solid ratio of 10 $1 / \mathrm{kg}$ for materials with particle size below $4 \mathrm{~mm}$ (with or without particle reduction)

[9] Official Journal of the European Communities, Council Decision of 19 December 2002, establishing criteria and procedures for acceptance of waste at landfills pursuant to Article 16 of and Annex II to Directive 1999/31/EC, 16.1.2003 